\title{
EFFECT OF THYROID HORMONES ON HISTAMINE FORMATION IN THE RAT
}

\author{
BY \\ T. BJURÖ, H. WESTLING AND H. WETTERQVIST \\ From the Department of Clinical Physiology, University of Gothenburg, Sweden \\ (Received September 6, 1961)

\begin{abstract}
Treatment with thyroxine or liothyronine increased the urinary excretion of free histamine in male and female rats under the influence of aminoguanidine, a histaminase inhibitor. There was no evidence for an altered catabolism of histamine in rats treated with liothyronine, since the same percentage of subcutaneously injected $\left[{ }^{14} \mathrm{C}\right]$-histamine appeared unchanged in the urine. After subcutaneous injection of $\left[{ }^{14} \mathrm{C}\right]$-L-histidine, rats treated with liothyronine excreted more $\left[{ }^{14} \mathrm{C}\right]$-histamine than control rats. An increased formation of $\left[{ }^{14} \mathrm{C}\right]$-histamine from $\left[{ }^{14} \mathrm{C}\right]$-histidine could also be demonstrated in vitro, in the glandular portion of the stomach, while no increase was found in the skin.
\end{abstract}

The metabolism and actions of histamine may be influenced by a number of endocrine glands. The relationship between histamine and the adrenocortical hormones has been most studied (Rose \& Browne, 1941 ; Haeger \& Kahlson, 1952 : Schayer, 1956 ; Telford \& West, 1960), but there are also suggestions of an effect of thyroid hormones on histamine metabolism. Thus Gotzl \& Dragstedt (1940) and Feldberg \& Loeser (1954) found the histamine content of the skin to be high in hyperthyroid states in rat and in man, whereas the skin histamine was low in myxoedema. Parratt \& West (1960) found an increase in the urinary excretion of histamine in the rat after treatment with L-thyroxine, and attributed this to a decrease in histaminase activity. They found no increase in the tissue histamine in rats treated with thyroxine.

It is known that there may be a connexion between adrenocortical and thyroid function. During studies on the effect of adrenalectomy on urinary histamine in the rat (Angervall, Bjurö \& Westling, 1961) the question arose whether changes in thyroid activity could be responsible for the effects observed. The action of Lthyroxine on the urinary excretion of histamine in rats treated with the histaminase inhibitor aminoguanidine was therefore examined. If the increase in urinary histamine reported by Parratt \& West (1960) was entirely due to diminished histaminase activity, it should not occur in rats treated with aminoguanidine.

\section{METHODS}

White rats of the Sprague-Dawley strain were given a constant amount (10 g daily) of a semi-synthetic food essentially free from histamine (Kahlson, Rosengren \& Westling, 1958). For urine collection the animals were kept in metabolism cages, and the urine collected 
under hydrochloric acid in 24-hr portions. Aminoguanidine sulphate was given subcutaneously once daily in a dose of about $20 \mathrm{mg} / \mathrm{kg}$. The excretion of free histamine was determined by bioassay on the guinea-pig ileum as described (Angervall, Bjurö \& Westling, 1961). Values are given as $\mu \mathrm{g}$ of free histamine base excreted per $24 \mathrm{hr}$.

Histamine content of skin was estimated by bioassay after extraction according to Code (1937).

$\left[{ }^{14} \mathrm{C}\right]$-Histamine was injected subcutaneously in a dose of about $10 \mu \mathrm{g}$. The $\left[{ }^{14} \mathrm{C}\right]-\mathrm{histamine}$ content of the urine was measured with the isotope dilution technique described by Lindell \& Schayer (1958). $1 \mathrm{ml}$. of the 24-hr sample of urine was taken and $40 \mathrm{mg}$ histamine base added as carrier. The histamine was then extracted with alkaline butanol and crystallized as the dipicrate. After removal of the picric acid, histamine was made to react with $p$-iodophenylsulphonyl chloride (pipsyl chloride). The radioactivity of the pipsylhistamine formed was measured on standard plates at infinite thickness under standardized conditions in a flow counter. The pipsylhistamine was recrystallized until the radioactivity was constant.

Histamine formation in vivo was determined by analysis of the urinary excretion of $\left[{ }^{14} \mathrm{C}\right]$-histamine during 24 hours after the subcutaneous injection of $\left[{ }^{14} \mathrm{C}\right]-\mathrm{L}$-histidine. The urine specimen was divided in two halves, and histamine-histidine carrier $(40 \mathrm{mg}$ histamine base and $50 \mathrm{mg}$ L-histidine monohydrochloride as diluent) was added to each half. Histamine (plus the small amount of $\left[{ }^{14} \mathrm{C}\right]$-histamine) was then extracted with butanol, crystallized as the dipicrate and then converted to pipsylhistamine and recrystallized until its radioactivity was constant.

Histidine decarboxylase activity of abdominal skin and the glandular portion of the stomach was determined in vitro with a modification of Schayer's technique (Kahlson, Rosengren, Westling \& White, 1958). The amount of $\left[{ }^{14} \mathrm{C}\right]$-histamine formed from $\left[{ }^{14} \mathrm{C}\right]$-histidine by minced tissue was determined after purification and crystallization as histamine dipicrate and pipsylhistamine. The incubation was carried out under nitrogen for $3 \mathrm{hr}$ at $37^{\circ} \mathrm{C}$. in a shaking incubator. Skin $(1.0 \mathrm{~g}$ minced tissue) was incubated with $1.5 \mathrm{ml}$. $0.1 \mathrm{M}$ sodium phosphate

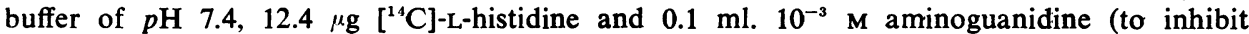
histaminase), and the glandular portion of the stomach ( 0.7 to $0.9 \mathrm{~g}$ minced tissue) with $1.0 \mathrm{ml}$. buffer, $12.4 \mu \mathrm{g}\left[{ }^{14} \mathrm{C}\right]-\mathrm{L}$-histidine and $0.1 \mathrm{ml} .10^{-3} \mathrm{M}$ aminoguanidine. The entire stomach wall of the glandular portion was used for incubation. Blanks were obtained by adding semicarbazide (a powerful histidine decarboxylase inhibitor), to give a final concentration of about $2 \times 10^{-2} \mathrm{M}$. After incubation for $3 \mathrm{hr}$, histamine-histidine carrier $(40 \mathrm{mg}$ of histamine base and $50 \mathrm{mg}$. of L-histidine monohydrochloride as diluent) was added, and allowed to mix well. The proteins were precipitated with trichloroacetic acid. Histamine was then extracted and converted to pipsylhistamine as described by Kahlson et al. (1958b). Pipsylhistamine was recrystallized until its radioactivity was constant. Histidine decarboxylase activity is given as counts $/$ min of $\left[{ }^{14} \mathrm{C}\right]$-histamine formed by a certain amount of tissue in $3 \mathrm{hr}$, with blank values and background radioactivity subtracted.

$\left[{ }^{14} \mathrm{C}\right]$-Radioactivity was measured at infinite thickness under standardized conditions in a flow counter with a background of 21 to 23 counts/min.

The radioactive substances were obtained from the Radiochemical Centre, Amersham, England: $\left[{ }^{14} \mathrm{C}\right]-$ histamine, labelled in the 2 position of the imidazole ring, specific activity $39.4 \mu \mathrm{c} / \mathrm{mg} ; 1 \mu \mathrm{g}$ giving about 2,500 counts $/ \mathrm{min}$ with $40 \mathrm{mg}$ histamine base as carrier and measured as pipsylhistamine under our conditions for measurements of radioactivity; $\left[{ }^{14} \mathrm{C}\right]-\mathrm{L}$-histidine, labelled at the same carbon atom as the radioactive histamine, specific activity $63.0 \mu \mathrm{C} / \mathrm{mg} ; 1 \mu \mathrm{g}$ of $\left[{ }^{14} \mathrm{C}\right]$-histamine formed from this $\left[{ }^{14} \mathrm{C}\right]$-histidine would give about 5,500 counts/min with $40 \mathrm{mg}$. histamine base as carrier.

Aliquots of the solutions of $\left[{ }^{14} \mathrm{C}\right]$-histamine and $\left[{ }^{14} \mathrm{C}\right]$-histidine used for injection were extracted for their content of $\left[{ }^{14} \mathrm{C}\right]$-histamine with the same methods as used for the urine samples.

L-Thyroxine and liothyronine (L-3,5,3-triiodothyronine) were used as the sodium salts, manufactured by Nyegaard, Oslo, and kindly supplied by Erco, Stockholm, Sweden. As recommended by the manufacturers, the hormones were first dissolved in $0.1 \mathrm{~N}$ sodium 
hydroxide and $0.1 \mathrm{~N}$ hydrochloric acid then added to give a $p \mathrm{H}$ of about 9.7. The daily dose of hormones was injected in a volume of 0.2 to $0.6 \mathrm{ml}$. Control rats were given the same volume of solvent (sodium hydroxide with hydrochloric acid). This is referred to as sodium hydroxide.

Mean values are given together with the standard error of the mean (mean \pm s.e.m.).

\section{RESULTS}

\section{Urinary excretion of free histamine}

The urinary excretion of free histamine in response to thyroxine and liothyronine was examined in 7 rats, which were also given aminoguanidine. It was found that both hormones caused a conspicuous increase in the urinary histamine, which started some 3 to 5 days after the beginning of injections, and continued for 7 to 10 days after the discontinuation of treatment (Fig. 1). A similar effect was not obtained with sodium hydroxide (Figs. 1 and 2). The experiments were not designed to compare the effectiveness of the two thyroid hormones but liothyronine seems to be rather more effective (Table 1). With both hormones, in various dosages, there appeared to be a parallelism between the effect on the body weight and the effect on the urinary histamine.

The effect of thyroid hormones was seen both in male and female rats (Figs. 1 and 2, Table 1). Due to the lower initial level of urinary histamine in the males, the increase brought about by the thyroid compounds appeared to be more pronounced in this sex, but the absolute increase was about the same, or slightly larger, in the females.

Fig. 2 shows that the effect of the thyroid hormones on the urinary histamine does not diminish on continued treatment. In the rat shown in Fig. 2 about $200 \mu \mathrm{g}$ excess histamine per day appeared in the urine even after 26 days of treatment with thyroxine.

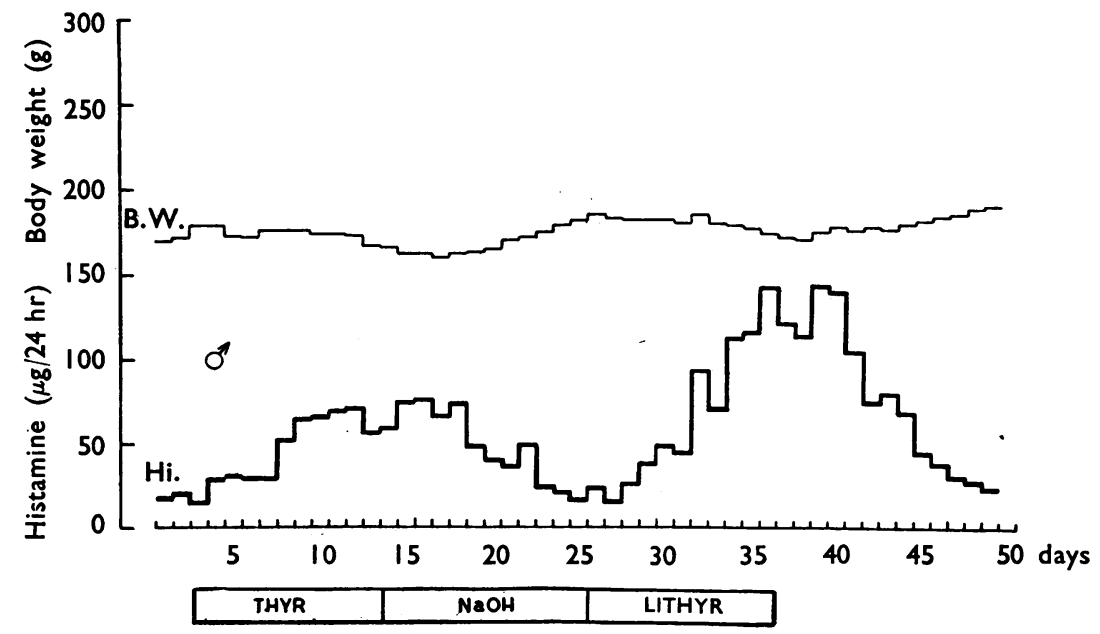

Fig. 1. Urinary excretion of histamine in $\mu \mathrm{g} / 24 \mathrm{hr}$ (Hi.) and body weight in $\mathrm{g}(\mathrm{B}$.W.) in a male rat during treatment with $0.2 \mathrm{mg}$ thyroxine (THYR), $0.2 \mathrm{ml}$. sodium hydroxide $(\mathrm{NaOH})$ or $0.04 \mathrm{mg}$ liothyronine (LITHYR), subcutaneously, once daily. The rat received in addition aminoguanidine $20 \mathrm{mg} / \mathrm{kg}$ subcutaneously once daily. 


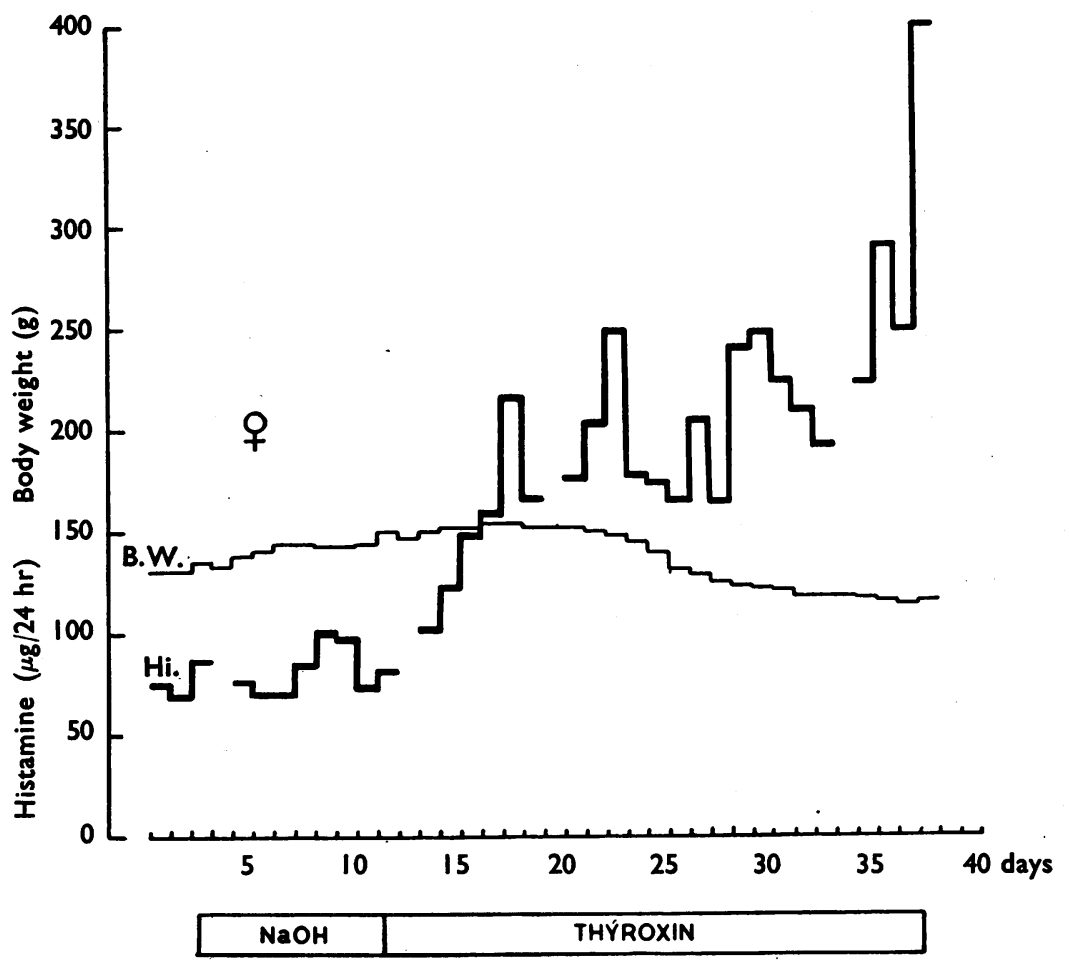

Fig. 2. Urinary excretion of histamine in $\mu \mathrm{g} / 24 \mathrm{hr}$ (Hi.) and body weight in $\mathrm{g}$ (B.W.) lin a female rat during treatment with $0.2 \mathrm{ml}$. sodium hydroxide $(\mathrm{NaOH})$ or $0.6 \mathrm{mg}$ thyroxine (THYROXIN), subcutaneously once daily. The rat received in addition aminoguanidine $20 \mathrm{mg} / \mathrm{kg}$ subcutaneously once daily

TABLE 1

EFFECT OF THYROID HORMONES ON URINARY HISTAMINE

Mean values are given for the urinary excretion of histamine during three days before treatment, and during the $7 \mathrm{th}, 8 \mathrm{th}$ and 9 th day of treatment, and expressed in $\mu \mathrm{g} / 24 \mathrm{hr}$. The animals were injected subcutaneously once daily with thyroxine, 0.2 or $0.6 \mathrm{mg}$, liothyronine, 0.04 or $0.12 \mathrm{mg}$, or with sodium hydroxide of the same $p \mathrm{H}$ and volume as the hormone solutions. All rats received in addition aminoguanidine, $20 \mathrm{mg} / \mathrm{kg}$ subcutaneously once daily

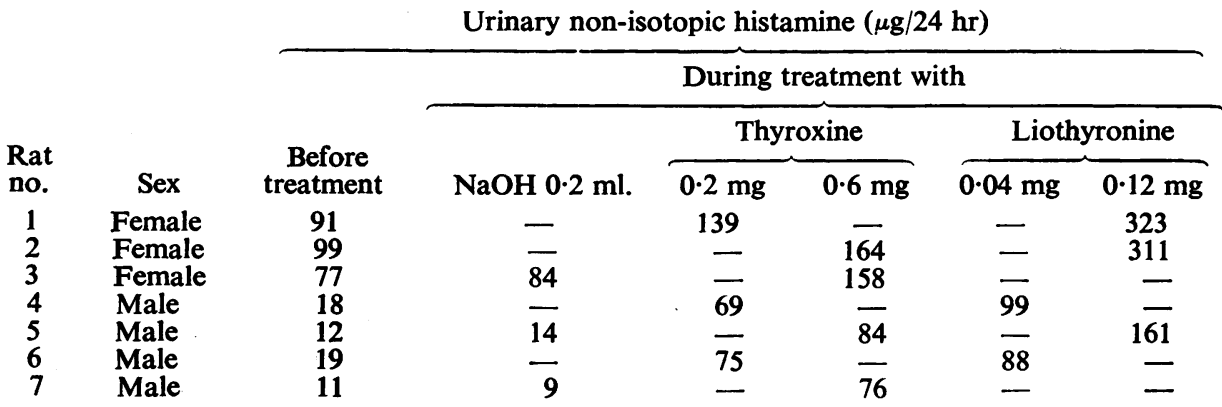


Thyroxine and liothyronine thus caused a pronounced and sustained increase in the urinary histamine in rats treated with aminoguanidine.

\section{Catabolism of injected $\left[{ }^{14} \mathrm{C}\right]$-histamine}

The effect of liothyronine on the catabolism of histamine was examined in 1 female and 3 male rats, which were compared with litter-mate controls. The results are given in Table 2 . The excreted $\left[{ }^{14} \mathrm{C}\right]$-histamine in $\%$ of the injected $\left[{ }^{14} \mathrm{C}\right]$-histamine was the same in the liothyronine group as in the control group.

TABLE 2

\section{EFFECT OF LIOTHYRONINE ON CATABOLISM OF INJECTED $\left[{ }^{14} \mathrm{C}\right]$-HISTAMINE}

8 litter-mate rats were injected once daily for 8 days with $0.12 \mathrm{mg}$ liothyronine or with sodium hydroxide of the same $p \mathrm{H}$ and volume as the hormone solution. All rats received in addition aminoguanidine, $20 \mathrm{mg} / \mathrm{kg}$ subcutaneously on the 7th and 8th day. At the 8th day all rats were given $10 \mu \mathrm{g}$ of $\left[{ }^{14} \mathrm{C}\right]$-histamine subcutaneously and urine collected for $24 \mathrm{hr}$. Values are given as excreted $\left[{ }^{14} \mathrm{C}\right]$-histamine in $\%$ of injected $\left[{ }^{14} \mathrm{C}\right]$-histamine. Values for urinary excretion of non-isotopic histamine are given as $\mu \mathrm{g} / 24 \mathrm{hr}$

\begin{tabular}{|c|c|c|c|c|c|c|}
\hline \multirow[b]{2}{*}{ Rat no. } & \multirow[b]{2}{*}{ Sex } & \multirow{2}{*}{ Treatment } & \multicolumn{2}{|c|}{ Body weight } & \multirow{2}{*}{$\begin{array}{l}{\left[{ }^{14} \mathrm{C}\right] \text {-Histamine }} \\
\text { in urine }\end{array}$} & \multirow{2}{*}{$\begin{array}{l}\text { Urinary non-isotopic } \\
\text { histamine } \\
\mu \mathrm{g} / 24 \mathrm{hr}\end{array}$} \\
\hline & & & Initial & $\overline{\text { Final }}$ & & \\
\hline $\begin{array}{l}1 \\
2 \\
3 \\
4\end{array}$ & $\begin{array}{l}\text { Female } \\
\text { Male } \\
\text { Male } \\
\text { Male }\end{array}$ & Liothyronine & $\begin{array}{l}186 \\
180 \\
176 \\
152\end{array}$ & $\begin{array}{l}169 \\
147 \\
144 \\
131\end{array}$ & $\begin{array}{l}35 \\
18 \\
13 \\
24\end{array}$ & $\begin{array}{l}348 \\
133 \\
218 \\
204\end{array}$ \\
\hline $\begin{array}{l}5 \\
6 \\
7 \\
8\end{array}$ & $\begin{array}{l}\text { Female } \\
\text { Male } \\
\text { Male } \\
\text { Male }\end{array}$ & $\mathrm{NaOH}$ & $\begin{array}{l}167 \\
166 \\
176 \\
186\end{array}$ & $\begin{array}{l}176 \\
179 \\
186 \\
190\end{array}$ & $\begin{array}{l}37 \\
21 \\
20 \\
16\end{array}$ & $\begin{array}{r}156 \\
39 \\
43 \\
42\end{array}$ \\
\hline
\end{tabular}

The female rats excreted about twice as much of the injected $\left[{ }^{14} \mathrm{C}\right]$-histamine in unchanged form as the male rats. The values observed are of the same magnitude as found in normal rats by Westling \& Wetterqvist (unpublished results).

It may be seen from Table 2 that the treatment with liothyronine had caused about the same increase in the urinary excretion of non-isotopic histamine as recorded previously (section 1). Still, the catabolism of $\left[{ }^{14} \mathrm{C}\right]$-labelled histamine, as reflected by its urinary excretion, was not measurably changed.

\section{Urinary excretion of $\left[{ }^{14} \mathrm{C}\right]$-histamine after subcutaneous injection of $\left[{ }^{14} \mathrm{C}\right]$-histidine}

Information about the rate of histamine formation from histidine in the intact rat can be obtained by analysis of the urinary $\left[{ }^{14} \mathrm{C}\right]$-histamine after subcutaneous injection of $\left[{ }^{14} \mathrm{C}\right]-\mathrm{L}$-histidine. Such experiments were performed on 4 female littermate rats, and the results are shown in Table 3.

It may be seen that the 2 rats treated with liothyronine had a substantially larger excretion of free, non-labelled histamine, as shown previously in section 1 . In addition, their excretion of $\left[{ }^{14} \mathrm{C}\right]$-histamine after injection of $\left[{ }^{14} \mathrm{C}\right]$-histidine was about twice as large as that of the control rats. There was thus some parallelism between the excretion of non-labelled histamine and of $\left[{ }^{14} \mathrm{C}\right]$-histamine. 
TABLE 3

\section{URINARY EXCRETION OF $\left.{ }^{\left[{ }^{14}\right.} \mathrm{C}\right]$-HISTAMINE AFTER SUBCUTANEOUS INJECTION OF $\left[{ }^{14} \mathrm{C}\right]$-HISTIDINE}

4 litter-mate rats were injected once daily for 8 days with $0.12 \mathrm{mg}$ liothyronine or with sodium hydroxide of the same $p \mathrm{H}$ and volume as the hormone solution. At the 8th day aminoguanidine $(20 \mathrm{mg} / \mathrm{kg})$ and $30 \mathrm{~min}$ later about $450 \mu \mathrm{g}$ of $\left[{ }^{14} \mathrm{C}\right]$-histidine were injected subcutaneously and the urine collected for $24 \mathrm{hr}$

\begin{tabular}{|c|c|c|c|c|c|c|}
\hline \multirow{2}{*}{$\begin{array}{l}\text { Rat } \\
\text { no. }\end{array}$} & \multirow{3}{*}{$\begin{array}{l}\text { Treatment } \\
\text { Liothyronine }\end{array}$} & \multicolumn{2}{|c|}{ Body weight } & \multicolumn{2}{|c|}{$\begin{array}{c}\text { Urinary excretion of } \\
{\left[{ }^{14} \mathrm{C}\right] \text {-histamine counts } / \mathrm{min} / 24 \mathrm{hr}}\end{array}$} & \multirow{2}{*}{$\begin{array}{c}\text { Urinary } \\
\text { non-isotopic } \\
\text { histamine } \\
\mu \mathrm{g} / 24 \mathrm{hr}\end{array}$} \\
\hline & & $\overparen{\text { Initial }}$ & Final & Duplicate assays & Average & \\
\hline 14 & & 138 & 132 & $\begin{array}{l}1,540^{\circ} \\
1,620\end{array}$ & 1,580 & 258 \\
\hline 15 & & 134 & 132 & $\begin{array}{l}1,640 \\
1,730\end{array}$ & 1,690 & 218 \\
\hline 16 & $\mathrm{NaOH}$ & 134 & 159 & $\begin{array}{l}600 \\
610\end{array}$ & 605 & 89 \\
\hline 17 & & 131 & 148 & $\begin{array}{l}900 \\
820\end{array}$ & 860 & 132 \\
\hline
\end{tabular}

Unfortunately the $\left[{ }^{14} \mathrm{C}\right]$-histidine available to us contained a small amount of $\left[{ }^{14} \mathrm{C}\right]$-histamine, as judged by analysis of the original solution used for injection into the rats (compare White, 1960). The amount of "preformed" $\left[{ }^{14} \mathrm{C}\right]$-histamine thus injected was calculated to correspond to 360 counts/min. It is known that in female rats given aminoguanidine about $1 / 3$ of subcutaneously injected $\left[{ }^{14} \mathrm{C}\right]-$ histamine is excreted unchanged into the urine (section 2 above; Westling, 1958 ; Westling \& Wetterqvist, unpublished). From the total $\left[{ }^{14} \mathrm{C}\right]$-histamine in the urine 120 counts/min should therefore be subtracted in order to obtain a closer estimate of the amount actually formed from $\left[{ }^{14} \mathrm{C}\right]$-histidine by the rat.

The increase in urinary excretion of non-isotopic histamine during treatment with liothyronine was thus accompanied by an increased excretion of $\left[{ }^{14} \mathrm{C}\right]$-histamine after subcutaneous injection of $\left[{ }^{14} \mathrm{C}\right]$-histidine. This could be due to a more rapid formation of $\left[{ }^{14} \mathrm{C}\right]$-histamine, or to a deficient catabolism of $\left[{ }^{14} \mathrm{C}\right]$-histamine, formed at a normal rate. The demonstration of an unchanged catabolism of injected $\left[{ }^{14} \mathrm{C}\right]$-histamine during treatment with liothyronine (section 2 ) speaks strongly in favour of the former possibility.

\section{Histidine decarboxylase activity in the skin and stomach}

The results so far obtained indicated that the rats treated with thyroid hormones formed histamine from histidine at a higher rate than normally. To see where this increased formation of histamine took place, in vitro experiments were performed. The histamine formation in abdominal skin and stomach was examined, since Schayer (1956) has found that adrenalectomy and administration of adrenocortical steroids elicit changes in the histamine-forming capacity of these tissues, the stomach reacting in a reverse manner to the skin.

The effect of liothyronine on histamine formation in vitro was examined in 2 groups of 11 female rats, the urine of which was not collected. The results are given in Table 4. Liothyronine caused a loss in body weight. The histidine decarboxylase activity of the glandular part of the stomach was about twice as 
TABLE 4

EFFECT OF LIOTHYRONINE ON HISTIDINE DECARBOXYLASE ACTIVITY

11 female rats were injected with $0 \cdot 1 \mathrm{mg}$ liothyronine subcutaneously once daily for 7 days; a control group of 11 female rats received the same volume of sodium hydroxide. Mean values \pm s.e.m. are given. $* 6$ rats. $† 5$ rats.

\begin{tabular}{|c|c|c|c|c|c|c|}
\hline \multirow[b]{3}{*}{ Treatment } & \multirow{2}{*}{\multicolumn{2}{|c|}{$\begin{array}{c}\text { Body } \\
\text { weight g }\end{array}$}} & \multicolumn{3}{|c|}{ Histidine decarboxylase activity } & \multirow{3}{*}{$\begin{array}{l}\text { Histamine } \\
\text { content of } \\
\text { abdominal } \\
\text { skin } \mu \mathrm{g} / \mathrm{g}\end{array}$} \\
\hline & & & \multirow{2}{*}{$\begin{array}{l}\text { Glandular } \\
\text { stomach } \\
\text { counts } / \mathrm{min}\end{array}$} & \multirow{2}{*}{$\begin{array}{c}\text { Glandular } \\
\text { stomach } \\
\text { counts } / \mathrm{min} / \mathrm{g} \\
\text { tissue }\end{array}$} & \multirow{2}{*}{$\begin{array}{c}\text { Skin } \\
\text { counts/ } \\
\text { min } / g \text { tissue }\end{array}$} & \\
\hline & Initial & Final & & & & \\
\hline $\begin{array}{l}\text { roup A: controls } 0.2 \mathrm{ml} \text {. } \\
\text { sodium hydroxide for } 7 \text { days. } \\
11 \text { rats }\end{array}$ & 153 & 175 & $1,390 \pm 278$ & $1,890 \pm 395$ & $21 \cdot 5 \pm 1 \cdot 81$ & $25 \cdot 3 \pm 2 \cdot 92^{*}$ \\
\hline $\begin{array}{l}\text { Group B: liothyronine } 0.1 \mathrm{mg} \\
\text { for } 7 \text { days. } 11 \text { rats }\end{array}$ & 160 & 153 & $2,690 \pm 272$ & $3,840 \pm 343$ & $20 \cdot 2 \pm 2 \cdot 09$ & $35 \cdot 0 \pm 1 \cdot 89 \dagger$ \\
\hline
\end{tabular}

large in the liothyronine-treated group, and the difference between this group and the control group (given sodium hydroxide) was statistically significant with $P<0.01$. The mean weight of the glandular stomach was slightly lower in the liothyronine group $(0.694 \pm 0.022 \mathrm{~g})$ than in the control group $(0.752 \pm 0.022 \mathrm{~g})$. The difference in histidine decarboxylase between liothyronine-treated and control rats was therefore even larger when the activity was calculated per $\mathrm{g}$ of tissue.

There was no difference between the histidine decarboxylase activity in the skin from liothyronine-treated rats and control rats (Table 4), but the actual content of non-isotopic histamine appeared to be larger in the liothyronine group.

\section{DISCUSSION}

The finding of an increased urinary excretion of free histamine during treatment with thyroid hormones confirms the observation by Parratt \& West (1960). However, the increase in urinary histamine is not likely to be caused by a diminished histaminase activity, since it occurred also in the present experiments, in which the action of histaminase (diamine oxidase) was inhibited by the administration of aminoguanidine during the whole experimental period. Aminoguanidine, in the dose given here, inhibits histaminase relatively completely (Schayer, Wu \& Smiley, 1954 ; Westling, 1958).

The thyroid hormones could, however, also interfere with another enzymatic pathway for the inactivation of histamine, namely, the enzyme responsible for the methylation of histamine. This enzyme is active also in rats given aminoguanidine (for example, Westling, 1958). However, there was no evidence for diminished methylation of histamine in response to liothyronine, since there was no change in $\%$ of injected $\left[{ }^{14} \mathrm{C}\right]$-histamine excreted in the urine in an unchanged form.

As causes of the elevation of urinary histamine during treatment with thyroid hormones, we may also consider: (1) increased intake of histamine, (2) release of histamine normally present in the body, and (3) increased formation of histamine. Of these (1) and (2) can be excluded with considerable certainty, the former because the animals were given a rigidly fixed intake of food with a constant composition. 
If the thyroid hormones released histamine from the tissues one should expect a lowering of the tissue histamine content. The available observations indicate that tissue histamine is, if anything, higher than normal in "hyperthyroid states" (Gotzl \& Dragstedt, 1940 ; Feldberg \& Loeser, 1954 ; Parratt \& West, 1960). Furthermore, a mere release of histamine should be transient if unaccompanied by an increased formation of the amine. The sustained increase in urinary histamine during prolonged treatment with thyroid hormones is apparent from Fig. 2 in the present paper.

By exclusion, increased formation with subsequent excretion is thus the most likely explanation for the high urinary output of histamine in rats treated with thyroid hormones. Direct support for this hypothesis is provided by the experiments with $\left[{ }^{14} \mathrm{C}\right]$-histidine. The finding of increased amounts of $\left[{ }^{14} \mathrm{C}\right]$-histamine in the urine after injection of $\left[{ }^{14} \mathrm{C}\right]$-histidine does not by itself prove that the rate of histamine formation is increased during treatment with liothyronine, but, taken together with the finding of an unchanged catabolism of $\left[{ }^{14} \mathrm{C}\right]$-histamine, it would seem to provide very strong evidence for a more rapid formation and turnover rate in the rat as a whole.

Supplementary evidence for increased histamine formation under the influence of liothyronine was found in the glandular part of the stomach; this tissue formed histamine in vitro at about twice the rate of the controls. In the skin, however, there was no measurable increase of the histamine formation in vitro. This is somewhat surprising, since both the present experiments and those of Gotzl \& Dragstedt (1940) and Feldberg \& Loeser (1954) indicate that the skin contains more histamine in "hyperthyroid" states. However, Parratt \& West (1960) found no change in skin histamine in rats treated with thyroxine.

Technical assistance given by Mr R. Edelman, Miss G. Jerkstrand and Mrs B.-L. Nilsson is gratefully acknowledged. The work was supported by a grant to $\mathrm{H}$. Westling from the "Statens Medicinska Forskningsråd."

\section{REFERENCES}

Angervall, L., BjuRö, T. \& Westling, H. (1961). The effect of adrenalectomy on the urinary excretion of histamine in the rat. Acta endocrinol., 36, 467-478.

CODE, C. F. (1937). The quantitative estimation of histamine in the blood. J. Physiol. (Lond.), 89, 257-268.

FELDBERG, W. \& LOESER, A. A. (1954). Histamine content of human skin in different clinical disorders. J. Physiol. (Lond.), 126, 286-292.

GotzL, F. R. \& DRAGSTEDT, C. A. (1940). Effect of thyroidectomy and of experimental hyperthyroidism upon histamine content of rat tissues. Proc. Soc. exp. Biol. N.Y., 45, 688-689.

HAEGER, K. \& KAHLSON, G. (1952). Disappearance of histaminase from the whole body following adrenalectomy in cats. Acta physiol. scand., 25, 255-258.

Kahlson, G., Rosengren, E. \& Westling, H. (1958a). Increased formation of histamine in the pregnant rat. J. Physiol. (Lond.), 143, 91-103.

KAHLSON, G., Rosengren, E., WestLING, H. \& White, T. (1958b). The site of increased formation of histamine in the pregnant rat. J. Physiol. (Lond.), 144, 337-348.

LINDELL, S.-E. \& SCHAYER, R. W. (1958). The renal removal of injected $\left[{ }^{14} \mathrm{C}\right]$-histamine from the blood in dogs. Brit. J. Pharmacol., 13, 44-51.

Parratt, J. R. \& West, G. B. (1960). Hypersensitivity and the thyroid gland. Int. Arch. Allergy, 16, 288-302.

Rose, B. \& Browne, J. S. L. (1941). Histamine content of tissues after adrenalectomy. Amer. J. Physiol., 131, 589-594. 
SCHAYER, R. W. (1956). Formation and binding of histamine by rat tissues in vitro. Amer. J. Physiol., 187, 63-65.

SCHAYER, R. W., WU, K. Y. T. \& SMILEY, R. L. (1954). Sources of urinary histamine in the rat. Amer. J. Physiol., 179, 481-485.

TELFORD, J. M. \& WEST, G. B. (1960). The effects of corticosteroids and related compounds on the histamine and 5-hydroxytryptamine content of rat tissues. Brit. J. Pharmacol., 15, 532-539.

Westling, H. (1958). The difference in the metabolism of injected $\left[{ }^{14} \mathrm{C}\right]$-histamine in male and female rats. Brit. J. Pharmacol., 13, 498-500.

Whrte, T. (1960). Formation and catabolism of histamine in cat brain in vivo. J. Physiol. (Lond.), 152, 299-308. 